\begin{tabular}{|c|c|}
\hline Title & Synthesis and biological eval uation of a MraY selective anal ogue of tunicamycins \\
\hline Author(s) & $\begin{array}{l}\text { Y amamoto, Kazuki; Sato, Toyotaka; Hikiji, Y uta; Katsuy ama, A kira; Matsumaru, Takanori; Y akushiji, Fumika; } \\
\text { Y okota, Shin-Ichi; Ichikawa, Satoshi }\end{array}$ \\
\hline Citation & $\begin{array}{l}\text { Nucleosides, nucleotides \& nucleic acids, 39(13), 349-364 } \\
\text { https://doi.org/10.1080/15257770.2019.1649696 }\end{array}$ \\
\hline Issue Date & 2019-09-30 \\
\hline Doc URL & http:/hdl.handle.net/2115/79340 \\
\hline Rights & $\begin{array}{l}\text { This is an A ccepted Manuscript of an article published by Taylor \& Francis in Nucleosides, nucleotides \& nucleic acids } \\
\text { on } 30 \text { Sep 2019, available online: http://www.tandfonline.com/doi full/10.1080/15257770.2019.1649696. }\end{array}$ \\
\hline Type & article (author version) \\
\hline File Information & WoS_91179_Ichikawa.pdf \\
\hline
\end{tabular}

Instructions for use 


\title{
Synthesis and biological evaluation of a MraY selective analogue of tunicamycins
}

Kazuki Yamamoto, ${ }^{\mathrm{a}}$ Toyotaka Sato, ${ }^{\mathrm{b}}$ Yuta Hikiji, ${ }^{\mathrm{a}}$ Akira Katsuyama, ${ }^{\mathrm{a}, \mathrm{c}}$ Takanori Matsumaru, ${ }^{\mathrm{a}, \mathrm{c},{ }^{\dagger} F u m i k a}$ Yakushiji,${ }^{\mathrm{a}, \mathrm{c}}$ Shin-ichi Yokota, ${ }^{\mathrm{b}}$ and Satoshi Ichikawa ${ }^{\mathrm{a}, \mathrm{c}^{*}}$

${ }^{a}$ Faculty of Pharmaceutical Sciences, Hokkaido University, Kita-12, Nishi-6, Kita-ku, Sapporo 060-0812, Japan

${ }^{b}$ Department of Microbiology, Sapporo Medical University School of Medicine, South1, West-17, Chuo-ku, Sapporo, 060-8556, Japan

${ }^{c}$ Center for Research and Education on Drug Discovery, Faculty of Pharmaceutical Sciences, Hokkaido University, Kita-12, Nishi-6, Kita-ku, Sapporo 060-0812, Japan

Current affiliation: Department of Chemistry, Faculty of Science and Technology, Keio University, Hiyoshi 3-14-1, Minatokita-ku, Yokohama, 223-8522, Japan

Corresponding Author: To whom correspondence should be addressed. Tel: (+81) 11706-3229. Fax: (+81) 11-706-4980. ichikawa@ pharm.hokudai.ac.jp.

\begin{abstract}
Tunicamycins, which are nucleoside natural products, inhibit both bacterial phospho- $N$ acetylmuraminic acid (MurNAc)-pentapeptide translocase (MraY) and human UDP- $N$ acetylglucosamine (GlcNAc): polyprenol phosphate translocase (GPT). The improved synthesis and detailed biological evaluation of an MraY-selective inhibitor, 2, where the GlcNAc moiety was modified to a MurNAc amide, has been described.
\end{abstract}

Keywords: antibacterial; nucleoside natural products; organic chemistry

\section{Introduction}


Bacterial phospho- $N$-acetylmuraminic acid (MurNAc)-pentapeptide translocase (MraY) is an enzyme that is responsible for the biosynthesis of peptidoglycan [1-3]. MraY produces lipid I by catalyzing the reaction between UDP-MurNAc-pentapeptide (Park's nucleotide) and undecaprenyl monophosphate. MraY is an essential bacterial enzyme and a good target for antibacterial drug discovery [4-6]. Tunicamycins [7-13] (1, FIGURE 1), which are isolated from the fermentation broths of Streptomyces lysosuperficus, are nucleoside natural products that inhibit MraY. Tunicamycins also strongly inhibit human UDP- $N$-acetylglucosamine (GlcNAc): polyprenol phosphate translocase (GPT), the enzyme responsible for the first $N$-acetylglucosamination of the $N$-linked glycopeptide in the endothelial reticulum [14].

[FIGURE 1 insert near here]

The use of tunicamycins as antibacterial agents is limited by the off-target inhibition of human GPT. Efforts to develop tunicamycin as an antibiotic require rational design to eliminate the cytotoxicity that arises from its off-target effects on human GPT activity. Our collaborative study [15] and others' [16] have elucidated the crystal structures of human GPT in complex with tunicamycin (FIGURE 2a). The complex structure of tunicamycins binding to MraY from Clostridium bolteae $\left(\mathrm{MraY}_{\mathrm{CB}}\right)$ has also been elucidated [17] (FIGURE 2b) and these complex structures can be utilized for the development of analogues. Structural analyses reveal the difference between human GPT and MraY in their mechanisms of inhibition by tunicamycin. It has been elucidated that a distinct difference exists in the interaction of transmembrane domain 9b (TM9b) and the helix in loop E in the carbohydrate recognition site between MraY and human GPT, and this structural information was exploited to design the MraY- 
specific inhibitor 2, where the GlcNAc moiety was modified to a MurNAc amide, as a potential antibiotics (FIGURE 3) [15]. Analogue $\mathbf{2}$ was identified as a highly selective MraY $_{\mathrm{AA}}$ inhibitor.

[FIGURE 2 insert near here]

These results in conjunction with our structure-activity relationship study with truncated analogues [18] make a potential modification to the GlcNAc moiety feasible to improve the biological activity for future molecular design. Although the inhibitory activity of 2 against MraY from Aquifex aeolicus (MraY $\mathrm{AA}_{\mathrm{A}}$ ) and human GTP was evaluated, its inhibitory activity against MraY from bacterial pathogens, cytotoxicity against human cells, and antibacterial activity have not yet been investigated. Here, we describe a detailed biological evaluation of $\mathbf{2}$ in addition to an improved synthesis of $\mathbf{2}$.

[FIGURE 3 insert near here]

\section{Results and Discussion}

Although a synthetic route of $\mathbf{2}$ has been established [15], there is room for improvement of the overall chemical yield to provide 2 , especially in the preparation of MurNAc amide 7. First, the synthesis of 7 was improved, as shown in SCHEME 1. The 3-hydroxy group of the known 2-deoxy-2-azidoglucose derivative 3 [19,20] was alkylated with triflate 4 , which proceeded with an inversion of stereochemistry at the $\alpha$ position of the carbonyl group of $\mathbf{4}$, to cleanly give 5 [21] in $81 \%$ yield. The methyl ester of 5 was quantitatively hydrolyzed by $\mathrm{Me}_{3} \mathrm{SnOH}$ in refluxing $\mathrm{ClCH}_{2} \mathrm{CH}_{2} \mathrm{Cl}[22,23]$, and the liberated carboxylic acid was condensed with methylamine in the presence of 4-(4,6dimethoxy-1,3,5-triazin-2-yl)-4-methylmorpholinium chloride (DMT-MM) [24,25] and 
$\mathrm{N}$-methylmorpholine in $\mathrm{CH}_{2} \mathrm{Cl}_{2}$ to afford $\mathbf{6}$ in $89 \%$ yield over two steps from $\mathbf{5}$. Removal of the TBS group at the 1-O-position of 6 by TBAF in the presence of acetic acid in THF quantitatively proceeded and the resulting alcohol 7 was converted to $O$ trichloroacetimidate $\mathbf{8}$ in $89 \%$ yield, which is a glycosyl donor in the synthesis of 2. Selective construction of the $11^{\prime}-\beta-1^{\prime \prime}$ - $\alpha$-trehalose-type linkage out of four possible anomers was achieved by treatment of 8 and 9 [26] with $\mathrm{TfOH}$ in $\mathrm{Et}_{2} \mathrm{O} / \mathrm{CH}_{2} \mathrm{Cl}_{2}$ at $0{ }^{\circ} \mathrm{C}$. Because of the effects of the large-scale synthesis, the yield of desired glycoside $\mathbf{1 0}$ improved to $78 \%$ (69\% in the previous small-scale synthesis) in a highly stereoselective manner, and the other three diastereomers were not obtained. The following four steps included transformation of the azide group to the acetamide group at the 2"-position, removal of the phthaloyl (Pht) group at the $\mathrm{N}^{10^{\prime}}$-position, installation of the 13methyltetradec-2-enoyl group onto the liberated amine, and global deprotection to successfully afford $\mathbf{2}$ [15]. This synthetic method greatly improved the total chemical yield of $\mathbf{2}$ compared to the method reported previously and provided a sufficient amount of material for further biological activity evaluation.

[SCHEME 1 insert near here]

The inhibitory activity for $\mathbf{1}$ and $\mathbf{2}$ against $\mathrm{MraY}_{\mathrm{AA}}$ are within a similar range (IC $\mathrm{I}_{50} 450$ $\mathrm{nM}$ for 1 vs. $640 \mathrm{nM}$ for 2) and were measured by using a thin-layer chromatographybased enzymatic assay using ${ }^{14} \mathrm{C}$-labeled Park's nucleotide [15]. In this study, the MraY inhibitory activity of $\mathbf{2}$ was evaluated by fluorescence-based MraY inhibitory assay [27] using dansylated Park's nucleotide and the purified MraY enzyme (S. aureus) (FIGURE 4). Analogue 2 exhibits potent inhibitory activity with the $\mathrm{IC}_{50}$ value of $87 \mathrm{nM}$, which displays 2.9-fold stronger activity than 1 ( IC $\left._{50} 250 \mathrm{nM}\right)$. The observed superior potency 
of 2 could be attributed to the different source of MraY.

[FIGURE 4 insert near here]

To gain insight into the molecular interaction of $\mathbf{2}$ with MraY and GPT, molecular modelling of the complex structures was investigated by using multi-ligand bimolecular association with energetics (eMBrAcE) [28]. eMBrAcE uses multiple minimizations in which each of the specified prepositioned ligands is minimized, in turn, with the receptor. Both 1 and 2 were docked to MraY (pdb code: 5JNQ) [17] and GPT (pdb code: 6BW5) [15], and the results of the docking calculations are illustrated in Figure 5. The MraY complex bound to both $\mathbf{1}$ and $\mathbf{2}$ has a similar overall structure, and the difference in the eMBrAcE total energy for each complex was relatively small (FIGURE 5a). In contrast, calculations of the GPT complex bound to each $\mathbf{1}$ or $\mathbf{2}$ resulted in different binding modes (FIGURE 5b). Compared to the structure of $\mathbf{1}$ bound to GPT, analogue $\mathbf{2}$ generates a steric clash between loop E and the $N$-methylpropanamide moiety introduced at the GlcNAc moiety of $\mathbf{2}$ in the place of. Loop E in the 2-GPT complex moved $2.8 \AA$ away from the $\mathrm{N}$-methylpropanamide moiety upon minimization in 2. This conformational change reduces the total energy of the complex and greatly affects ligand recognition. These calculations support the reduced off-target activity to GPT and selectivity for MraY that was observed for 2 .

[FIGURE 5 insert near here]

Selective toxicity is a key issue in the development of tunicamycins in developing as antibacterial agents. Analogue 2 did not show any toxicity up to $100 \mu \mathrm{M}$ whereas $\mathbf{1}$ 
showed cytotoxicity in a dose-dependent manner and cell viability was ca. $10 \%$ at a concentration of $100 \mu \mathrm{M}$ treatment (FIGURE 6). As a result, 2 has been suggested to be a non-toxic MraY selective inhibitor.

[FIGURE 6 insert near here]

Finally, the antibacterial activity of $\mathbf{2}$ was examined against the ESKAPE pathogens (Enterococcus faecium, Staphylococcus aureus, Klebsiella pneumoniae, Acinetobacter baumannii, Pseudomonas aeruginosa, and Enterobacter species), which are the leading cause of nosocomial infections throughout the world [29,30]. (TABLE 1). Tunicamycin $\mathrm{V}$ (1) is known to inhibit limited gram-positive bacterial pathogens such as $S$. aureus and E. faecium [7]. Analogue 2 retains weak antibacterial activity against $S$. aureus although the MIC value was reduced by a factor of four compared to 1. Tunicamycins are also known to inhibit undecaprenyl-phosphate $\alpha$-N-acetylglucosaminyl 1-phosphate transferase (WecA) for the synthesis of lipopolysaccharide and enterobacterial common antigen [31,34] and TarO/TagO, which are the first enzymes in the wall teichoic acid biosynthetic pathway in gram-positive bacteria [32-34]. These enzymes utilize UDPGlcNAc as a substrate similar to GPT. Presumably, the antibacterial activity of tunicamycins is due by not only from the inhibition of MraY but also from the inhibition of WecA, TarO and TagO, and the observed decrease in the antibacterial activity of 2 against $S$. aureus and E. faecium, both of which are gram-positive bacteria, could be attributed to a decrease in the inhibitory activity against these other enzymes. However, the three-dimensional structure of these enzymes has not been elucidated yet, and more detailed study will be necessary. 
[TABLE 1 insert near here]

\section{Conclusion}

Improved synthesis and detailed biological evaluation of the MraY-selective inhibitor, 2, where the GlcNAc moiety was modified to a MurNAc amide, was described. The synthetic method modified in this study greatly improved the total chemical yield of the preparation of $\mathbf{2}$. Analogue $\mathbf{2}$ exhibits potent inhibitory activity against MraY with an $\mathrm{IC}_{50}$ value of $87 \mathrm{nM}$, which shows 2.9 -fold stronger activity than that of $\mathbf{1}$. Molecular modelling of the complex structures indicated that $\mathbf{2}$ generates a steric clash between the $\mathrm{N}$-methylpropanamide moiety introduced in the place of the GlcNAc moiety of $\mathbf{2}$ and loop E. Analogue 2 did not show any toxicity against HepG2 cells up to $100 \mu \mathrm{M}$, and $\mathbf{2}$ was found to be a nontoxic selective MraY inhibitor. Although 2 retains weak antibacterial activity against $S$. aureus, the MIC value was reduced compared to $\mathbf{1}$. These results suggest that enhancement of the antibacterial activity of $\mathbf{2}$ is necessary. One strategies to develop nontoxic tunicamycin analogues with potent antibacterial activity might be to introduce additional chemical modifications into 2 to increase the affinity to MraY. The complex structure of muraymycin D2 [35], which is a natural product that shows strong and selective MraY inhibitory activity, could be very useful to guide the structure-based drug design of tunicamycin analogues in the future.

\section{Experimental sections}

General experimental methods. NMR spectra were reported in parts per million $(\delta)$ relative to tetramethylsilane $(0.00 \mathrm{ppm})$ as internal standard otherwise noted. Coupling constant $(J)$ was reported in herz $(\mathrm{Hz})$. Abbreviations of multiplicity were as follows; s: singlet, d; doublet, t: triplet, q: quartet, m: multiplet, br: broad. Data were presented as 
follows; chemical shift (multiplicity, integration, coupling constant). Assignment was based on ${ }^{1} \mathrm{H}-{ }^{1} \mathrm{H}$ COSY, HMBC and HMQC NMR spectra. Purity of 2 tested for biological evaluation was confirmed to be $>95 \%$ by ${ }^{1} \mathrm{H}$ NMR analyses.

tert-Butyldimethylsilyl

2-azido-2-deoxy-4,6-O-isopropylidene-3-O-[(R)-1-

(methoxycarbonyl)ethyl]- $\beta$-D-glucopyranoside (5)

A solution of 3 (200 mg, $0.556 \mathrm{mmol})$ in THF (5 mL) was treated with NaHMDS (1.9 $\mathrm{M}$ in THF, $307 \mu \mathrm{L}, 0.584 \mathrm{mmol} .1 .05$ equiv.) at $0{ }^{\circ} \mathrm{C}$ for $30 \mathrm{~min}$. A solution of methyl (S)-2-(trifluoromethanesulfonyloxy)-propanoate [36] (4, $154 \mathrm{mg}, 0.652 \mathrm{mmol}, 1.17$ equiv.) in THF ( $1 \mathrm{~mL})$ was added dropwise to the mixture at $0{ }^{\circ} \mathrm{C}$ and the reaction mixture was stirred for $30 \mathrm{~min}$. The reaction was quenched with sat. aq. $\mathrm{NH}_{4} \mathrm{Cl}$, and the resulting mixture was extracted with EtOAc. The organic layer was washed with brine, dried over $\mathrm{Na}_{2} \mathrm{SO}_{4}$, filtered and concentrated in vacuo. The residue was purified by flash silica gel column chromatography $(\phi 1.4 \times 19 \mathrm{~cm}$; hexane/EtOAc $=9 / 1 \rightarrow 4 / 1)$ to afford $5(201 \mathrm{mg}$, $81 \%)$ as a colorless syrup. ${ }^{1} \mathrm{H} \mathrm{NMR}\left(\mathrm{CDCl}_{3}, 400 \mathrm{MHz}\right) \delta 4.49\left(\mathrm{~d}, 1 \mathrm{H}, \mathrm{H}-1, J_{1,2}=7.7 \mathrm{~Hz}\right)$, $4.39\left(\mathrm{q}, 1 \mathrm{H}, \mathrm{CHCH}_{3}, J=7.0 \mathrm{~Hz}\right), 3.85\left(\mathrm{dd}, 1 \mathrm{H}, \mathrm{H}-6, J_{\mathrm{gem}}=10.6, J_{6,5}=5.4 \mathrm{~Hz}\right), 3.77(\mathrm{~s}$, $3 \mathrm{H}, \mathrm{CO}_{2} \mathrm{Me}$ ), 3.76 (t, 1H, H-6, J = $\left.10.4 \mathrm{~Hz}\right), 3.66(\mathrm{t}, 1 \mathrm{H}, \mathrm{H}-4, J=9.3 \mathrm{~Hz}), 3.39$ (t, 1H, H$3, J=9.3 \mathrm{~Hz}), 3.27\left(\mathrm{dd}, 1 \mathrm{H}, \mathrm{H}-2, J_{2,3}=9.5, J_{2,1}=7.7 \mathrm{~Hz}\right), 3.17\left(\mathrm{td}, 1 \mathrm{H}, \mathrm{H}-5, J=9.7, J_{5,6}\right.$ $=5.4 \mathrm{~Hz}), 1.48(\mathrm{~s}, 3 \mathrm{H}$, isopropylidene $), 1.39\left(\mathrm{~d}, 3 \mathrm{H}, \mathrm{CHCH}_{3}, J=7.0 \mathrm{~Hz}\right), 1.38(\mathrm{~s}, 3 \mathrm{H}$, isopropylidene), 0.91 (s, 9H, $\left.{ }^{t} \mathrm{BuSi}\right), 0.13$ (s, 3H, MeSi), 0.12 (s, 3H, MeSi); ${ }^{13} \mathrm{C} \mathrm{NMR}$ $\left(\mathrm{CDCl}_{3}, 100 \mathrm{MHz}\right) \delta 173.4,99.5,97.4,79.9,76.1,74.3,68.5,67.1,62.2,52.0,29.2,25.6$, 19.2, 19.1, 18.0, -4.3, -5.1; ESIMS-HR calcd for $\mathrm{C}_{19} \mathrm{H}_{36} \mathrm{~N}_{3} \mathrm{O}_{7} \mathrm{Si} 446.2323$, found 446.2304; $[\alpha]^{24} \mathrm{D}-36.24\left(c\right.$ 1.05, $\left.\mathrm{CHCl}_{3}\right)$. This compound is known compound and data are in good accordance with those reported previously [20]. 
methylcarbamoyl)ethyl]- $\beta$-D-glucopyranoside (6)

A solution of 5 (270 mg, $0.606 \mathrm{mmol})$ and $\mathrm{Me}_{3} \mathrm{SnOH}$ (548 mg, $3.03 \mathrm{mmol}, 5.0$ equiv.) in 1,2-dichloroethane $(3.5 \mathrm{~mL})$ was refluxed for $2 \mathrm{~h}$. The reaction mixture was cooled and concentrated in vacuo. The residue was diluted with EtOAc, and the mixture was washed with $1 \mathrm{M}$ aq. $\mathrm{HCl}$ and brine, dried over $\mathrm{Na}_{2} \mathrm{SO}_{4}$, filtered and concentrated in vacuo to afford a crude carboxylic acid. A solution of the crude carboxylic acid, $\mathrm{MeNH}_{2} \cdot \mathrm{HCl}(81.8$ $\mathrm{mg}, 1.21 \mathrm{mmol}, 2.0$ equiv.) and $N$-methylmorpholine (136 $\mu \mathrm{L}, 1.21 \mathrm{mmol}, 2.0$ equiv.) in $\mathrm{MeOH}(3.5 \mathrm{~mL})$ was treated with DMT-MM (284 mg, $0.909 \mathrm{mmol}, 1.5$ equiv.) at room temperature, and the mixture was stirred for $3 \mathrm{~h}$. Additional $\mathrm{MeNH}_{2} \cdot \mathrm{HCl}(40.9 \mathrm{mg}), \mathrm{N}$ methylmorpholine $(68 \mu \mathrm{L})$ and DMT-MM $(142 \mathrm{mg})$ was added to the reaction mixture, and the mixture was stirred for another $2 \mathrm{~h}$. The reaction mixture was concentrated in vacuo, and the residue was diluted with EtOAc. The mixture was washed with sat. aq. $\mathrm{NaHCO}_{3}$ and brine, dried over $\mathrm{Na}_{2} \mathrm{SO}_{4}$, filtered and concentrated in vacuo. The residue was purified by flash silica gel column chromatography $(\phi 1.1 \times 19 \mathrm{~cm}$; hexane/EtOAc $=$ 2/1) to afford an inseparable mixture of 6 and trimethoxytriazine (292 $\mathrm{mg}$ ) as a white solid. The ration of 6 to trimethoxytriazine was $2: 1$ judged by ${ }^{1} \mathrm{H}$ NMR, and the mixture contained $241 \mathrm{mg}$ of 6 (89\% over 2 steps). ${ }^{1} \mathrm{H} \mathrm{NMR}\left(\mathrm{CDCl}_{3}, 400 \mathrm{MHz}\right) \delta 7.36(\mathrm{br} \mathrm{d}, 1 \mathrm{H}$, $\mathrm{N} H, J=3.6 \mathrm{~Hz}), 4.64\left(\mathrm{~d}, 1 \mathrm{H}, \mathrm{H}-1, J_{1,2}=7.3 \mathrm{~Hz}\right), 4.37\left(\mathrm{q}, 1 \mathrm{H}, \mathrm{CHCH}_{3}, J=6.8 \mathrm{~Hz}\right), 3.86$ $\left(\mathrm{dd}, 1 \mathrm{H}, \mathrm{H}-6, J_{\mathrm{gem}}=10.9, J_{6,5}=5.4 \mathrm{~Hz}\right), 3.77(\mathrm{t}, 1 \mathrm{H}, \mathrm{H}-6, J=10.6 \mathrm{~Hz}), 3.65(\mathrm{t}, 1 \mathrm{H}, \mathrm{H}-4$, $J=9.3 \mathrm{~Hz}), 3.31\left(\mathrm{dd}, 1 \mathrm{H}, \mathrm{H}-2, J_{2,3}=10.0, J_{2,1}=7.3 \mathrm{~Hz}\right), 3.23-3.17(\mathrm{~m}, 2 \mathrm{H}, \mathrm{H}-3, \mathrm{H}-5)$, $2.85(\mathrm{~d}, 3 \mathrm{H}, \mathrm{NMe}, J=5.0 \mathrm{~Hz}), 1.49(\mathrm{~s}, 3 \mathrm{H}$, isopropylidene $), 1.38\left(\mathrm{~d}, 3 \mathrm{H}, \mathrm{CHCH}_{3}, J=6.8\right.$ $\mathrm{Hz}$ ), 1.37 (s, 3H, isopropylidene), 0.93 (s, 9H, ${ }^{t} \mathrm{BuSi}$ ), 0.16 (s, 3H, MeSi), 0.14 (s, 3H, $\mathrm{MeSi}) ;{ }^{13} \mathrm{C} \mathrm{NMR}\left(\mathrm{CDCl}_{3}, 100 \mathrm{MHz}\right) \delta 174.0,99.6,97.9,77.9,77.7,75.1,67.7,67.2,62.1$, 
29.2, 25.8, 25.6, 19.6, 19.1, 18.0, -4.3, -5.1; ESIMS-HR calcd for $\mathrm{C}_{19} \mathrm{H}_{37} \mathrm{~N}_{4} \mathrm{O}_{6} \mathrm{Si}$ 445.2482, found $445.2471 ;[\alpha]^{22} \mathrm{D}-9.45\left(c 1.01, \mathrm{CHCl}_{3}\right)$.

\section{2-Azido-2-deoxy-4,6-O-isopropylidene-3-O-[(R)-1-(N-methylcarbamoyl)ethyl]-D- glucopyranose (7)}

A solution of an inseparable mixture of $\mathbf{6}$ and trimethoxytriazine $(482 \mathrm{mg}$, the ration of 6 to trimethoxytriazine was 3:1 judged by ${ }^{1} \mathrm{H}$ NMR, and the mixture contained $421 \mathrm{mg}$, $0.948 \mathrm{mmol})$ in THF $(1 \mathrm{~mL})$ was treated with $\mathrm{AcOH}(141 \mu \mathrm{L}, 2.46 \mathrm{mmol}, 2.6$ equiv. $)$ and TBAF (1.0 $\mathrm{M}$ in THF, $1.23 \mathrm{~mL}, 1.23 \mathrm{mmol}, 1.3$ equiv.) at $0{ }^{\circ} \mathrm{C}$ for $1 \mathrm{~h}$. The reaction mixture was diluted with EtOAc, and the resulting mixture was washed with sat. aq. $\mathrm{NaHCO}_{3}$ and brine, dried over $\mathrm{Na}_{2} \mathrm{SO}_{4}$, filtered and concentrated in vacuo. The residue was purified by silica gel column chromatography $(\phi 1.4 \times 10.5 \mathrm{~cm}$; hexane $/$ EtOAc $=1 / 2$ $\rightarrow 1 / 3)$ to afford $7(292 \mathrm{mg}, 93 \%, \alpha / \beta=3 / 5)$ as a colorless syrup. ${ }^{1} \mathrm{H} \mathrm{NMR}\left(\mathrm{CDCl}_{3}, 400\right.$ MHz) $\delta 7.40($ br d, $1 \mathrm{H}, \mathrm{NH} \beta, J=4.1 \mathrm{~Hz}), 7.18(\mathrm{br} \mathrm{d}, 0.6 \mathrm{H}, \mathrm{NH} \alpha, J=4.5 \mathrm{~Hz}), 5.42(\mathrm{~d}$, $\left.0.6 \mathrm{H}, \mathrm{H}-1 \alpha, J_{1,2}=3.6 \mathrm{~Hz}\right), 4.79\left(\mathrm{~d}, 1 \mathrm{H}, \mathrm{H}-1 \beta, J_{1,2}=7.7 \mathrm{~Hz}\right), 4.37\left(\mathrm{q}, 1 \mathrm{H}, \mathrm{CHCH}_{3} \beta, J=\right.$ $6.8 \mathrm{~Hz}$ ), 4.33 (q, 0.6H, $\mathrm{CHCH}_{3} \alpha, J=6.8 \mathrm{~Hz}$ ), 3.95-3.89 (obscured, 0.6H, H-5 $)$ ), 3.91 $\left(\mathrm{dd}, 1 \mathrm{H}, \mathrm{H}-6 \beta, J_{\text {gem }}=10.9, J_{6,5}=5.4 \mathrm{~Hz}\right), 3.85\left(\mathrm{dd}, 0.6 \mathrm{H}, \mathrm{H}-6 \alpha, J_{\text {gem }}=10.4, J_{6,5}=5.0\right.$

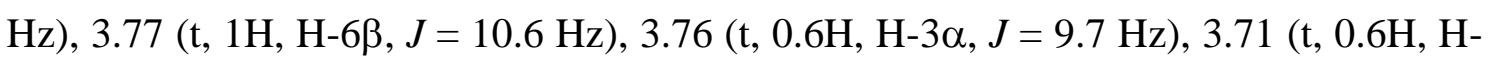
$6 \alpha, J=10.4 \mathrm{~Hz}), 3.67(\mathrm{t}, 1 \mathrm{H}, \mathrm{H}-4 \beta, J=9.3 \mathrm{~Hz}), 3.61(\mathrm{t}, 0.6 \mathrm{H}, \mathrm{H}-4 \alpha, J=9.3 \mathrm{~Hz}), 3.37$ $\left(\mathrm{dd}, 1 \mathrm{H}, \mathrm{H}-2 \beta, J_{2,3}=10.0, J_{2,1}=7.7 \mathrm{~Hz}\right), 3.30\left(\mathrm{dd}, 0.6 \mathrm{H}, \mathrm{H}-2 \alpha, J_{2,3}=10.0, J_{2,1}=3.6 \mathrm{~Hz}\right)$,

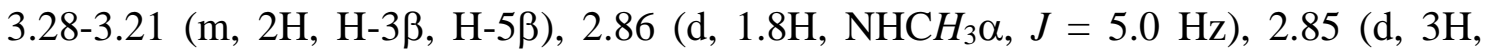
$\mathrm{NHCH}_{3} \beta, J=5.0 \mathrm{~Hz}$ ), 1.50 (br s, 4.8H, isopropylidene), 1.41-1.38 (m, 9.6H, isopropylidene, $\left.\mathrm{CHCH}_{3}\right) ;{ }^{13} \mathrm{C} \mathrm{NMR}\left(\mathrm{CDCl}_{3}, 100 \mathrm{MHz}\right) \delta 174.9,174.7,99.7,99.7,97.2$, $92.5,78.2,78.1,77.6,76.2,75.7,75.0,67.1,66.4,63.2,62.5,62.1,29.2,29.1,26.2,25.9$, 
19.7, 19.5, 19.2, 19.1; ESIMS-HR calcd for $\mathrm{C}_{13} \mathrm{H}_{23} \mathrm{~N}_{4} \mathrm{O}_{6} 331.1618$, found 331.1631; $[\alpha]^{27} \mathrm{D}+122.19\left(c 1.00, \mathrm{CHCl}_{3}\right)$.

2-Azido-2-deoxy-4,6-O-isopropylidene-3-O-[(R)-1-(N-methylcarbamoyl)ethyl]- $\beta-D-$ glucopyranosyl trichloroacetimidate (8)

A solution of 7 (243 mg, $0.736 \mathrm{mmol}$ ) in $\mathrm{CH}_{2} \mathrm{Cl}_{2} / \mathrm{CCl}_{3} \mathrm{CN}$ (v/v 4/1, $8 \mathrm{~mL}$ ) was treated with $\mathrm{K}_{2} \mathrm{CO}_{3}$ powder $(81.3 \mathrm{mg}, 0588 \mathrm{mmol}, 0.8$ equiv. $)$ at $0{ }^{\circ} \mathrm{C}$, and the mixture was stirred at room temperature for $19 \mathrm{~h}$. The insoluble solid was filtered off through a Celite pad and washed with $\mathrm{CH}_{2} \mathrm{Cl}_{2}$. The filtrate was concentrated in vacuo, the residue was purified by silica gel column chromatography $\left(\phi 1.4 \times 8.5 \mathrm{~cm}\right.$, treated with $\mathrm{Et}_{3} \mathrm{~N}$; hexane/EtOAc $=$ $3 / 2 \rightarrow 1 / 1)$ to afford $8(341 \mathrm{mg}, 98 \%, \alpha / \beta=2 / 25)$ as a colorless oil. ${ }^{1} \mathrm{H} \mathrm{NMR}\left(\mathrm{CDCl}_{3}\right.$, $500 \mathrm{MHz}) \delta 8.84(\mathrm{~s}, 1 \mathrm{H}$, imidate $\mathrm{NH}), 7.20(\mathrm{br} \mathrm{d}, 1 \mathrm{H}$, amide $\mathrm{NH}, J=4.0 \mathrm{~Hz}), 5.77$ (d, $\left.1 \mathrm{H}, \mathrm{H}-1, J_{1,2}=8.6 \mathrm{~Hz}\right), 4.41\left(\mathrm{q}, 1 \mathrm{H}, \mathrm{CHCH}_{3}, J=6.9 \mathrm{~Hz}\right), 3.98\left(\mathrm{dd}, 1 \mathrm{H}, \mathrm{H}-6, J_{\mathrm{gem}}=10.9\right.$, $\left.J_{6,5}=5.7 \mathrm{~Hz}\right), 3.79(\mathrm{t}, 1 \mathrm{H}, \mathrm{H}-6, J=10.6 \mathrm{~Hz}), 3.73(\mathrm{t}, 1 \mathrm{H}, \mathrm{H}-4, J=9.2 \mathrm{~Hz}), 3.67(\mathrm{dd}, 1 \mathrm{H}$, $\left.\mathrm{H}-2, J_{2,3}=9.7, J_{2,1}=8.6 \mathrm{~Hz}\right), 3.41-3.35(\mathrm{~m}, 2 \mathrm{H}, \mathrm{H}-3, \mathrm{H}-5), 2.86\left(\mathrm{~d}, 3 \mathrm{H}, \mathrm{N}-\mathrm{CH} H_{3}, J=5.2\right.$ $\mathrm{Hz}), 1.51\left(\mathrm{~s}, 3 \mathrm{H}\right.$, isopropylidene), $1.41\left(\mathrm{~d}, 3 \mathrm{H}, \mathrm{CHCH}_{3}, J=6.9 \mathrm{~Hz}\right), 1.39(\mathrm{~s}, 3 \mathrm{H}$, isopropylidene); ${ }^{13} \mathrm{C} \mathrm{NMR}\left(\mathrm{CDCl}_{3}, 100 \mathrm{MHz}\right) \delta 173.7,160.7,99.9,97.2,90.2,78.1,78.0$, 74.4, 67.8, 65.2, 61.8, 29.0, 25.9, 19.7, 19.2; ESIMS-HR calcd for $\mathrm{C}_{15} \mathrm{H}_{23} \mathrm{Cl}_{3} \mathrm{~N}_{5} \mathrm{O}_{6}$ 474.0708, found 474.0726; $[\alpha]^{14} \mathrm{D}+6.37\left(c 0.81, \mathrm{CHCl}_{3}\right)$.

3-(Benzyloxymethyl)-1-(11S-6,10-dideoxy-11-O-\{2-azido-2-deoxy-4,6-Oisopropylidene-3-O-[(R)-1-(N-methylcarbamoyl)ethyl]- $\alpha$-D-gluco-hexopyranosyl]2,3:8,9-di-O-isopropylidene-5-O-(methoxymethyl)-10-phthalimido-L-galacto- $\beta$-Dallo-undecodialdo-1,4-furanose-11,7-pyranos-1-yl)uracil (10) 
A solution of 8 (338 mg, $0.712 \mathrm{mmol}, 2.0$ equiv.), 9 (278 mg, $0.356 \mathrm{mmol}, 1.0$ equiv.) and molecular sieves $4 \mathrm{~A}(500 \mathrm{mg})$ in $\mathrm{Et}_{2} \mathrm{O} / \mathrm{CH}_{2} \mathrm{Cl}_{2}$ (v/v 5/1, $\left.10 \mathrm{~mL}\right)$ was treated with

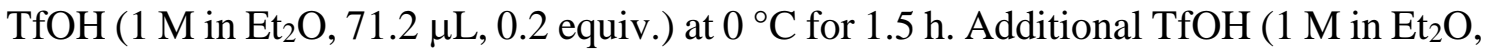
$71.2 \mu \mathrm{L}, 0.2$ equiv.) was added to the reaction mixture at $0{ }^{\circ} \mathrm{C}$, and the mixture was stirred for $7.5 \mathrm{~h}$. The reaction was quenched with $\mathrm{Et}_{3} \mathrm{~N}(0.5 \mathrm{~mL})$ and the mixture was warmed to room temperature. The insoluble solid was filtered off through a Celite pad and washed with EtOAc. The filtrate was washed with sat. aq. $\mathrm{NaHCO}_{3}$ and brine, dried over $\mathrm{Na}_{2} \mathrm{SO}_{4}$, filtered and concentrated in vacuo. The residue was purified by flash silica gel column chromatography $(\phi 1.4 \times 18 \mathrm{~cm}$; hexane/EtOAc $=1 / 2 \rightarrow 1 / 3 \rightarrow 1 / 4)$ to afford $\mathbf{1 0}(303 \mathrm{mg}$, $78 \%$ ) as a white powder. ${ }^{1} \mathrm{H} \mathrm{NMR}\left(\mathrm{CDCl}_{3}, 500 \mathrm{MHz}\right) \delta 7.85$ (br s, 2H, Phth), 7.74 (br s, 2H, Phth), 7.38-7.27 (m, 6H, Ph, H-6), 6.61 (q, 1H, NH-Me, J=4.6 Hz), 5.83 (d, 1H, H$\left.1^{\prime}, J_{1^{\prime}, 2^{\prime}}=3.4 \mathrm{~Hz}\right), 5.75\left(\mathrm{~d}, 1 \mathrm{H}, \mathrm{H}-5, J_{5,6}=8.0 \mathrm{~Hz}\right), 5.51\left(\mathrm{~d}, 1 \mathrm{H}, \mathrm{N}-\mathrm{CH}_{2}-\mathrm{OBn}, J_{\mathrm{gem}}=9.7\right.$ $\mathrm{Hz}), 5.49\left(\mathrm{~d}, 1 \mathrm{H}, \mathrm{N}-\mathrm{CH}_{2}-\mathrm{OBn}, J_{\mathrm{gem}}=9.7 \mathrm{~Hz}\right), 5.26\left(\mathrm{~d}, 1 \mathrm{H}, \mathrm{H}-11^{\prime}, J_{11^{\prime}}, 10^{\prime}=8.6 \mathrm{~Hz}\right), 5.01$ $\left(\mathrm{d}, 1 \mathrm{H}, \mathrm{H}-1^{\prime \prime}, J_{1^{\prime \prime}, 2^{\prime \prime}}=3.4 \mathrm{~Hz}\right), 4.93\left(\mathrm{dd}, 1 \mathrm{H}, \mathrm{H}-3^{\prime}, J_{3^{\prime}, 2^{\prime}}=6.9, J_{3^{\prime}, 4^{\prime}}=4.9 \mathrm{~Hz}\right), 4.77-4.74(\mathrm{~m}$, 2H, H-2', H-9'), 4.71-4.67 (m, 4H, Bn, O-CH2-OMe), 4.32 (t, 1H, H-10', J = 9.2 Hz), 4.16-4.11 (m, 2H, CH-CH $\left.3, \mathrm{H}-5^{\prime}\right), 4.09\left(\mathrm{dd}, 1 \mathrm{H}, \mathrm{H}-8^{\prime}, J_{8^{\prime}, 9^{\prime}}=4.6, J_{8^{\prime}, 7^{\prime}}=1.7 \mathrm{~Hz}\right), 4.03-3.99$ (m, 2H, H-4', H-7'), 3.91-3.84 (m, 2H, H-5", H-6"), 3.66 (t, 1H, H-6", J = 10.0 Hz), 3.51 (t, 1H, H-4", $J=9.2 \mathrm{~Hz}), 3.46$ (t, 1H, H-3", $J=9.2 \mathrm{~Hz}$ ), 3.43 (s, 3H, OMe), 3.24 (dd, 1H, H-2", $\left.J_{2 ", 3 "}=9.2, J_{2 " 1 "}=3.4 \mathrm{~Hz}\right), 2.64\left(\mathrm{~d}, 3 \mathrm{H}, \mathrm{N}-\mathrm{CH}_{3}, J=4.6 \mathrm{~Hz}\right), 2.20\left(\mathrm{~m}, 1 \mathrm{H}, \mathrm{H}-6^{\prime}\right)$, 1.77 (m, 1H, H-6'), 1.68 (s, 3H, isopropylidene), 1.60 (s, 3H, isopropylidene), 1.43 (s, 3H, isopropylidene), $1.37(\mathrm{~s}, 3 \mathrm{H}$, isopropylidene), $1.36(\mathrm{~s}, 3 \mathrm{H}$, isopropylidene), $1.33(\mathrm{~s}, 3 \mathrm{H}$, isopropylidene), $1.30\left(\mathrm{~d}, 3 \mathrm{H}, \mathrm{CH}-\mathrm{CH}_{3}, J_{\mathrm{CH} 3, \mathrm{CH}}=6.9 \mathrm{~Hz}\right) ;{ }^{13} \mathrm{C} \mathrm{NMR}\left(\mathrm{CDCl}_{3}, 125 \mathrm{MHz}\right) \delta$ 173.5, 162.6, 150.8, 139.9, 138.0, 134.2 (broad), 132.1 (broad), 128.4, 127.8, 115.3, 110.8, $102.5,100.3,100.3,99.7,98.6,91.9,87.8,84.1,79.4,77.8,75.8,75.7,75.6,74.9,74.5$, $72.4,70.5,69.6,64.4,64.2,62.2,56.4,55.0,33.8,29.1,28.2,27.4,26.6,25.7,25.6,19.5$, 
19.1; ESIMS-HR calcd for $\mathrm{C}_{52} \mathrm{H}_{66} \mathrm{~N}_{7} \mathrm{O}_{19} 1092.4408$, found $1092.4406 ;[\alpha]^{18}{ }_{\mathrm{D}}+54.60(c$ $\left.0.97, \mathrm{CHCl}_{3}\right)$.

\section{MurNAc analogue (2)}

A solution of $\mathbf{1 0}(22.1 \mathrm{mg}, 20.2 \mu \mathrm{mol})$ in pyridine $(1 \mathrm{~mL})$ was treated with thioacetic acid $(0.5 \mathrm{~mL})$ at room temperature for 5 days under the dark condition. The reaction mixture was concentrated in vacuo and co-evaporated with toluene. The residue was purified by silica gel column chromatography $\left(\phi 0.9 \times 9 \mathrm{~cm} ; \mathrm{CHCl}_{3} / \mathrm{MeOH}=0 \% \rightarrow 1 \%\right.$ $\rightarrow 2 \%)$ to afford a corresponding acetamide $(20.3 \mathrm{mg}, 91 \%)$ as a white powder.

A solution of the corresponding acetamide $(19.6 \mathrm{mg}, 17.7 \mu \mathrm{mol})$ in EtOH (1 mL) was treated with ethylenediamine (11.6 $\mu \mathrm{L}, 177 \mu \mathrm{mol}, 10$ equiv.) and the mixture was heated at $80{ }^{\circ} \mathrm{C}$ for $5 \mathrm{~h}$. The reaction mixture was cooled to room temperature, concentrated in vacuo and co-evaporated with toluene. The residue was purified by silica gel column chromatography $\left(\phi 0.4 \times 4.5 \mathrm{~cm}\right.$, treated with $0.1 \% \mathrm{Et}_{3} \mathrm{~N} ; \mathrm{CHCl}_{3} / \mathrm{MeOH}=3 \% \rightarrow 5 \% \rightarrow$ $8 \%)$ to afford the crude amine. A solution of the amine in $\mathrm{CH}_{2} \mathrm{Cl}_{2}(0.5 \mathrm{~mL})$ was treated with $\mathrm{Et}_{3} \mathrm{~N}$ (7.38 $\mu \mathrm{L}, 53.1 \mu \mathrm{mol}, 3.0$ equiv.), HOAt (2.4 mg, $17.7 \mu \mathrm{mol}, 1.0$ equiv.), carboxylic acid ( $8.5 \mathrm{mg}, 35.4 \mu \mathrm{mol}, 2.0$ equiv.) and EDCI (7.5 mg, $38.9 \mu \mathrm{mol}, 2.2$ equiv.) sequentially at room temperature for $1.5 \mathrm{~h}$. Methanol $(0.5 \mathrm{~mL})$ was added to the reaction mixture and the mixture was stirred for $2 \mathrm{~h}$. The reaction mixture was concentrated in vacuo, and the residue was purified by silica gel column chromatography $(\phi 0.4 \times 4.5 \mathrm{~cm}$; hexane/EtOAc $=1 / 1 \rightarrow \mathrm{CHCl}_{3} / \mathrm{MeOH}=0 \% \rightarrow 1 \% \rightarrow 2 \%$ ) to afford a protected-MurNAc analogue (14.9 mg, $70 \%$ over 2 steps) as a white powder.

A solution of the protected-MurNAc analogue $(14.8 \mathrm{mg}, 12.3 \mu \mathrm{mol})$ in $\mathrm{CH}_{2} \mathrm{Cl}_{2}(0.6$ mL) was treated with $\mathrm{BCl}_{3}\left(1 \mathrm{M}\right.$ in $\mathrm{CH}_{2} \mathrm{Cl}_{2}, 369 \mu \mathrm{L}, 369 \mu \mathrm{mol}, 30$ equiv.) at $-78{ }^{\circ} \mathrm{C}$ for $15 \mathrm{~min}$, and the mixture was stirred at $0{ }^{\circ} \mathrm{C}$ for $30 \mathrm{~min}$. Sodium methoxide $(5 \mathrm{M}$ in $\mathrm{MeOH}$, 
$369 \mu \mathrm{L}, 1845 \mu \mathrm{mol}, 150$ equiv.) was added to the mixture at $0{ }^{\circ} \mathrm{C}$, and the resulting mixture was stirred at room temperature for $10 \mathrm{~min}$. The mixture was neutralized with Dowex $50 \mathrm{~W} \times 4$ and the insoluble solid was filtered off. The filtrate was concentrated in vacuo, the residue was purified by HPLC (YMC-Pack R\&D ODS D-ODS-5-A, $250 \times 20$ $\mathrm{mm}, 0.1 \%$ TFA $\left.60 \% \mathrm{MeCN} / \mathrm{H}_{2} \mathrm{O}\right)$ to afford $2(9.1 \mathrm{mg}, 81 \%)$ as a white solid. Spectrum data was shown in ref. 15.

\section{Fluorescence-based MraY assay}

Reactions were carried out in 384-well microplate. Reaction mixtures contained, in a final volume of $20 \mu \mathrm{L}, 50 \mathrm{mM}$ Tris- $\mathrm{HCl}(\mathrm{pH} 7.6), 50 \mathrm{mM} \mathrm{KCl}, 25 \mathrm{mM} \mathrm{MgCl}_{2}, 0.2 \%$ Triton $\mathrm{X}$ 100, 8\% glycerol, $50 \mu \mathrm{M}$ C55-P and $10 \mu \mathrm{M}$ UDP-MurNAc-dansylpentapeptide. The reaction was initiated by the addition of Staphylococcus aureus MraY enzyme (55 ng/5 $\mu \mathrm{L} /$ well). After $3 \mathrm{~h}$ incubation at room temperature, the formation of dansylated lipid I was monitored by fluorescence enhancement (excitation at $355 \mathrm{~nm}$, emission at $535 \mathrm{~nm}$ ) by using infinite M200 microplate reader (Tecan). The inhibitory effects of each compound were determined in the MraY assays described above. The mixtures contained $2 \%$ dimethyl sulfoxide in order to increase the solubility of the compounds. Commercial tunicamycins was purchased from FUJIFILM Wako Pure Chemical Corporation.

\section{Molecular modelling}

The interaction energy calculation of $\mathbf{1}$ and $\mathbf{2}$ with MraY and GPT were performed by employing the automated mechanism of Multi-Ligand Bimolecular Association with Energetics using embrace minimization program of Macro Model ver. 11.4 of Schrödinger suites. Complexes of tunicamycin-MraY (PDB: 5JNQ) and tunicamycin- 
GPT (PDB: 6BW5) were used as templates. The complexes of analogue 2 and MraY/GPT were prepared by manual docking. The calculations were performed by using OPLS-3 force field in water as a solvent. Embrace minimization calculations were performed using an energy difference mode, in which the calculation is performed first on the receptor, then on the ligand and finally on the complex, taking as input the complexes obtained. The energy difference is then calculated using the equation ( $\Delta E=\Delta E_{\text {complex }}-$ $\left.\Delta E_{\text {receptor }}-\Delta E_{\text {ligand }}\right)$.

\section{Evaluation of cytotoxicity}

Cytotoxic activity of the compounds against HepG2 cell was measured using Cell Counting Kit- 8 according to manufacturer's protocol. Briefly, HepG2 cells $\left(1 \times 10^{5}\right.$ cells/well) in a 96 well plate were cultures in D-MEM (Low Glucose) medium containing $10 \%$ fetal bovine serum in the presence of test compounds at $37{ }^{\circ} \mathrm{C}$ for $24 \mathrm{~h}$ under $5 \%$ $\mathrm{CO}_{2}$ atmosphere. A solution of Cell Counting Kit-8 reagent in medium (1:10) was added. The plates were incubated at $37{ }^{\circ} \mathrm{C}$ for $2 \mathrm{~h}$ under $5 \% \mathrm{CO}_{2}$ atmosphere, then 450 $\mathrm{nm} \backslash$ absorbance was measured.

\section{Evaluation of antibacterial activity}

MICs were determined by a microdilution broth method as recommended by the CLSI with cation-adjusted Mueller-Hinton broth (CA-MHB). Serial two-fold dilutions of each compound were made in appropriate broth, and the plates were inoculated with $5 \times 10^{4}$ CFU of each strain in a volume of $0.1 \mathrm{~mL}$. Plates were incubated at $37^{\circ} \mathrm{C}$ for $18 \mathrm{~h}$ and then MICs were scored. 


\section{Associated content}

The manuscript was written through contributions of all authors. / All authors have given approval to the final version of the manuscript.

\section{Notes}

The authors declare no competing financial interest.

\section{Acknowledgement}

This research was supported in part by JSPS Grant-in-Aid for Scientific Research (B) (Grant Number 16H05097 to S.I.), Grant-in Aid for Scientific Research on Innovative Areas "Frontier Research on Chemical Communications" (No $18 H 04599$ to S.I.), Takeda Foundation, The Tokyo Biomedical Research Foundation and was partly supported by Hokkaido University, Global Facility Center (GFC), Pharma Science Open Unit (PSOU), funded by MEXT under "Support Program for Implementation of New Equipment Sharing System", the Platform Project for Supporting Drug Discovery and Life Science Research (Basis for Supporting Innovative Drug Discovery and Life Science Research; BINDS) from the Japan Agency for Medical Research and Development (AMED).

\section{References}

[1] Bouhss, A.; Mengin-Lecreulx, D.; Le Beller, D.; Van Heijenoort, J. Topological analysis of the MraY protein catalyzing the first membrane step of peptidoglycan synthesis. Mol. Microbiol. 1999, 34. 576-585.

[2] Bouhss, A.; Trunkfield, A. E.; Bugg, T. D.; Mengin-Lecreulx, D. The biosynthesis of peptidoglycan lipid-linked intermediates. FEMS Microbiol. Rev. 2008, 32, 208-33. 
[3] Al-Dabbagh, B.; Henry, X.; El Ghachi, M.; Auger, G.; Blanot, D.; Parquet, C.; Mengin-Lecreulx, D.; Bouhss, A. Active Site mapping of MraY, a member of the polyprenyl-phosphate $N$-acetylhexosamine 1-phosphate transferase superfamily, catalyzing the first membrane step of peptidoglycan biosynthesis. Biochemistry 2008, 47, 8919-8928.

[4] Kimura, K.; Bugg, T. D. H. Recent advances in antimicrobial nucleoside antibiotics targeting cell wall biosynthesis. Nat. Prod. Rep. 2003, 20, 252-273.

[5] Bugg, T. D. H.; Lloyd, A. J.; Roger, D. I. Phospho-MurNAc-pentapeptide translocase (MraY) as a target for antibacterial agents and antibacterial proteins. Infect. Dis. Drug Targets 2006, 6, 85-106.

[6] Winn, M.; Goss, R. J. M.; Kimura, K.; Bugg, T. D. H. Antimicrobial nucleoside antibiotics targeting cell wall assembly: Recent advances in structure-function studies and nucleoside biosynthesis. Nat. Prod. Rep. 2010, 27, 279-304.

[7] Takatsuki, A.; Arima, K.; Tamura, G. Tunicamycin, a new antibiotic. I. J. Antibiot. 1971, 24, 215-223.

[8] Takatsuki, A.; Tamura, G. Tunicamycin, a new antibiotic. II. J. Antibiot. 1971, 24, 224-231.

[9] Takatsuki, A.; Tamura, G. Tunicamycin, a new antibiotic. III. J. Antibiot. 1971, 24, 232-238.

[10] Takatsuki, A.; Tamura, G. Effect of tunicamycin on the synthesis of macromolecules in cultures of chick embryo fibroblasts infected with new castle disease virus. $J$. Antibiot. 1971, 24, 785-795.

[11] Ito, T.; Kodama, Y.; Kawamura, K.; Suzuki, K.; Takatsuki, A.; Tamura, G. The structure of tunicaminyl uracil, a degradation product of tunicamycin. Agric. Biol. Chem. 1977, 41, 2303-2305. 
[12] Takatsuki, A.; Kawamura, K.; Okina, M.; Kodama, Y.; Ito, T.; Tamura, G. The structure of tunicamycin. Agric. Biol. Chem. 1977, 41, 2307-2309.

[13] Ito, T.; Takatsuki, A.; Kawamura, K.; Sato, K.; Tamura, G. Isolation and structures of components 11 of tunicamycin. Agric. Biol. Chem. 1980, 44, 695-698.

[14] Lehrman, M. A. Biosynthesis of $N$-acetylglucosamine-P-P-dolichol, the committed step of asparagine-linked oligosaccharide assembly. Glycobiology 1991, 1, 553-562.

[15] Yoo, J.; Mashalidis, E. H.; Kuk, A. C. Y.; Yamamoto, K.; Kaeser, B.; Ichikawa, S.; Lee, S. Y. GlcNAc-1-P-transferase-tunicamycin complex structure reveals basis for inhibition of N-glycosylation. Nat. Struct. Mol. Biol. 2018, 25, 217-224.

[16] Dong, Y. Y.; Wang, H.; Pike, A. C. W.; Cochrane, S. A.; Hamedzadeh, S.; Wyszyński, F. J.; Bushell, S. R.; Royer, S. F.; Widdick, D. A.; Sajid, A.; Boshoff, H. I.; Park. Y.; Lucas, R.; Liu, W. M.; Lee, S. S.; Machida, T.; Minall, L.; Mehmood, S.; Belaya, K.; Liu, W. W.; Chu, A.; Shrestha, L.; Mukhopadhyay, S. M. M.; Damerell, C. S.; Chalk, R.; Brown, N. A. B.; Bibb, M. J.; Barry, C. E. III; Robinson, C. V.; Beeson, D.; Davis, B. G.; Carpenter, E. P. Structures of DPAGT1 explain glycosylation disease mechanism and advance TB antibiotic design. Cell 2018, 175, 1045-1058.

[17] Hakulinen, J. K.; Hering, J.; Brändén, G.; Chen, H.; Snijder, A.; Ek, M.; Johansson, P. MraY-antibiotic complex reveals details of tunicamycin mode of action. Nat. Chem. Biol. 2017, 13, 265-267.

[18] Yamamoto, K.; Katsuyama, A.; Ichikawa, S. Structural requirement of tunicamycin V for MraY inhibition. Bioorg. Med. Chem. 2019, 27, 1714-1719.

[19] Kinzy, W.; Schmidt, R. R. Glycosyl imidates. 16. Synthesis of the trisccharide of the repeating unit of the capsular polysaccharide of Neisseria meningitidis (Serogroup L). Liebigs Ann. Chem. 1985, 8, 1537-1545. 
[20] Orgueira, H. A.; Bartolozzi, A.; Schell, P.; Litjens, R. E. J. N.; Palmacci, E. R.; Seeberger, P. H. Modular synthesis of Heparin Oligosaccharides. Chem. Eur. J. 2003, 9, 140-169.

[21] Kinzy, W.; Schmidt, R. R. Glycosyl imidates. 25. Muramic acid as glycosyl donor and glycosyl acceptor. Leibigs Ann. Chem. 1987, 5, 407-415.

[22] Nicolaou, K. C.; Nevalainen, M.; Zak, M.; Bulat, S.; Bella, M.; Safina, B. S. Synthetic Studies on Thiostrepton: Construction of Thiostrepton Analogues with the Thiazoline-Containing Macrocycle. Angew. Chem. Int. Ed. 2003, 42, 3418-3424.

[23] Nicolaou, K. C.; Estrada, A. A.; Zak, M.; Lee, S. H.; Safina, B. S. A Mild and Selective Method for the Hydrolysis of Esters with Trimethyltin Hydroxide. Angew. Chem. Int. Ed. 2005, 44, 1378-1382.

[24] Kunishima, M.; Kawachi, C.; Iwasaki, F.; Terao, K.; Tani, S. Synthesis and characterization of 4-(4,6-dimethoxy-1,3,5-triazin-2-yl)-4-methylmorpholinium chloride. Tetrahedron Lett. 1999, 40, 5327-5330.

[25] Kunishima, M.; Kawachi, C.; Hioki, K.; Terao, K.; Tani, S. Formation of carboxamides by direct condensation of carboxylic acids and amines in alcohols using a new alcohol- and water-soluble condensing agent: DMT-MM. Tetrahedron 2001, 57, 1551-1558.

[26] Yamamoto, K.; Yakushiji, F.; Matsumaru, T.; Ichikawa, S. Total synthesis of tunicamycin V. Org. Lett. 2018, 20, 256-259.

[27] Stachyra, T.; Dini, C.; Ferrari, P.; Bouhss, A.; van Heijenoort, J.; Lecreulx, D. M.; Blanot, D.; Bilton, J.; Le Beller, D. Fluorescence detection-based functional assay for high-throughput screening for MraY. Antimicrob. Agents Chemother. 2004, 48, 897-902.

[28] Guvench, O.; Weiser, J.; Shenkin, P. S.; Kolossváry, I.; Still, W. C. Application of 
the frozen atom approximation to the GB/SA continuum model for solvation free energy. J. Comput. Chem. 2002, 23, 214-221.

[29] Rice, L. B. Federal funding for the study of antimicrobial resistance in nosocomial pathogens: No ESKAPE. J. Infect. Dis. 2008, 197, 1079-1081.

[30] Pendleton, J. N.; Gorman, S. P.; Gilmore, B. F. Clinical relevance of the ESKAPE pathogens. Expert Rev. Anti-infect. Ther. 2013, 11, 297-308.

[31] Dabbagh, B. A.; Lecreulx, D. M.; Bouhss, A. Purification and characterization of the bacterial UDP-GlcNAc: undecaprenyl-phosphate GlcNAc-1-phosphate transferase WecA. J. Bacteriol. 2008, 190, 7141-7146.

[32] Soldo, B.; Lazarevic, V.; Karamata, D. $\operatorname{tag} O$ is involved in the synthesis of all anionic cell-wall polymers in Bacillus subtilis 168. Microbiology 2002, 148, 20792087.

[33] Campbell, J.; Singh, A. K.; Santa Maria, J. P. Jr.; Kim, Y.; Brown, S.; Swoboda, J. G.; Mylonakis, E.; Willkinson, B. J.; Walker, S. Synthetic lethal compound combinations reveal a fundamental connection between wall teichoic acid and peptidoglycan biosynthesis in staphylococcus aureus. ACS Chem. Biol. 2011, 6, 106116.

[34] Price, N. P. J.; Momany, F. A. Modeling bacterial UDP-HexNAc: polyprenol-P HexNAc-1-P transferase. Glycobiology 2005, 15, 29R-42R.

[35] Chung, B. C.; Mashalidis E. H.; Tanino, T.; Kim, M.; Matsuda, A.; Hong, J.; Ichikawa, S.; Lee, S. Y. Structural insights into inhibition of lipid I production in bacterial cell wall synthesis. Nature 2016, 533, 557-560.

[36] Chattopadhyay, A. K.; Jakkepally, S.; Berger, G.; Hanessian, S. Total Synthesis of Isodaphlongamine H: A Possible Biogenetic Conundrum. Angew. Chem. Int. Ed. 2016, 55, 2577-2581. 


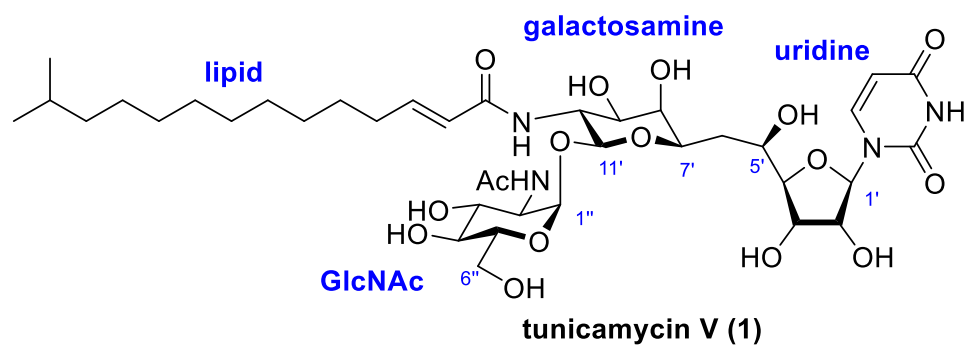

FIGURE 1. Structure of tunicamycin V 


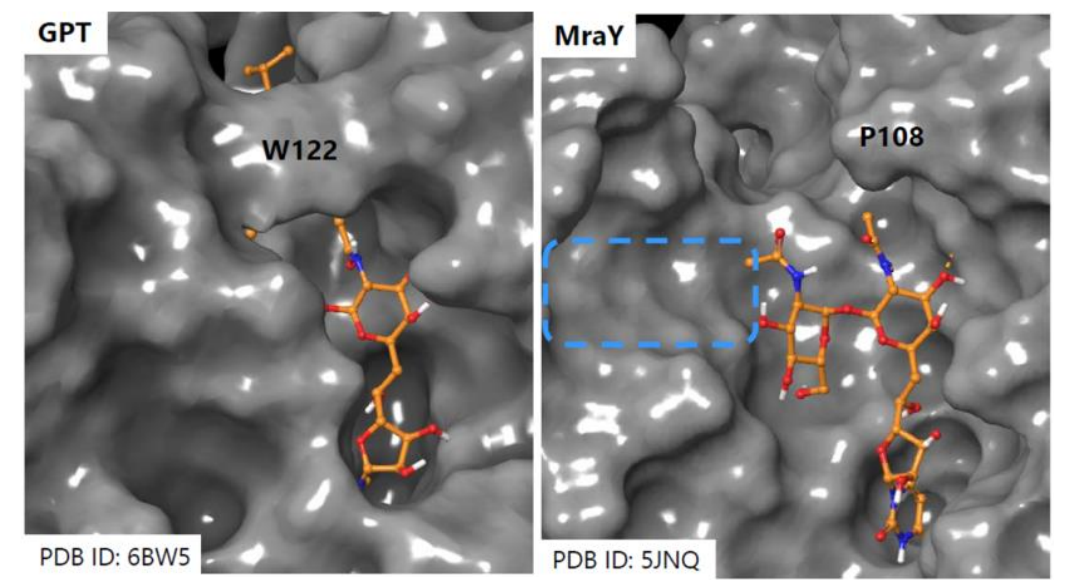

FIGURE 2. Comparison of human GPT and $\mathrm{MraY}_{\mathrm{CB}}$ in complex with tunicamycins 


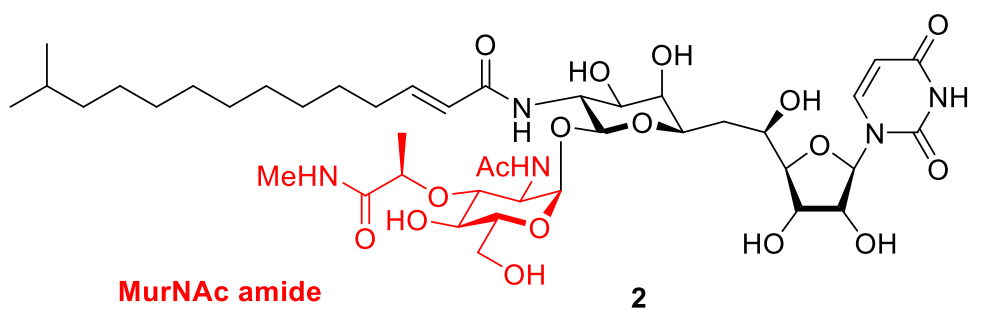

FIGURE 3. Structure of tunicamycin analogue 2 
SCHEME 1. Improved synthesis of 2

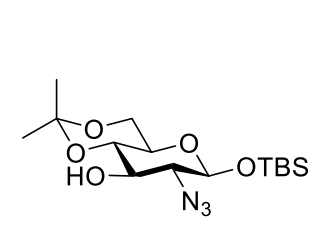

3<smiles>COC(=[OH+])C(C)[OH+]</smiles>

NaHMDS

$\frac{\mathrm{THF}, 0{ }^{\circ} \mathrm{C}}{81 \%}$

(ref 21)

$\mathrm{MeO}_{2}$

\begin{tabular}{l|l} 
1) $\mathrm{Me}_{3} \mathrm{SnOH}$ & $\begin{array}{c}\text { 2) } \mathrm{MeNH}_{3} \mathrm{Cl} \\
\mathrm{ClCH}_{2} \mathrm{CH}_{2} \mathrm{Cl} \\
\text { reflux }\end{array}$ \\
& $\begin{array}{c}\text { NMT-MM } \mathrm{NMM}, \mathrm{MeOH} \\
89 \% \text { over } 2 \text { steps }\end{array}$
\end{tabular}
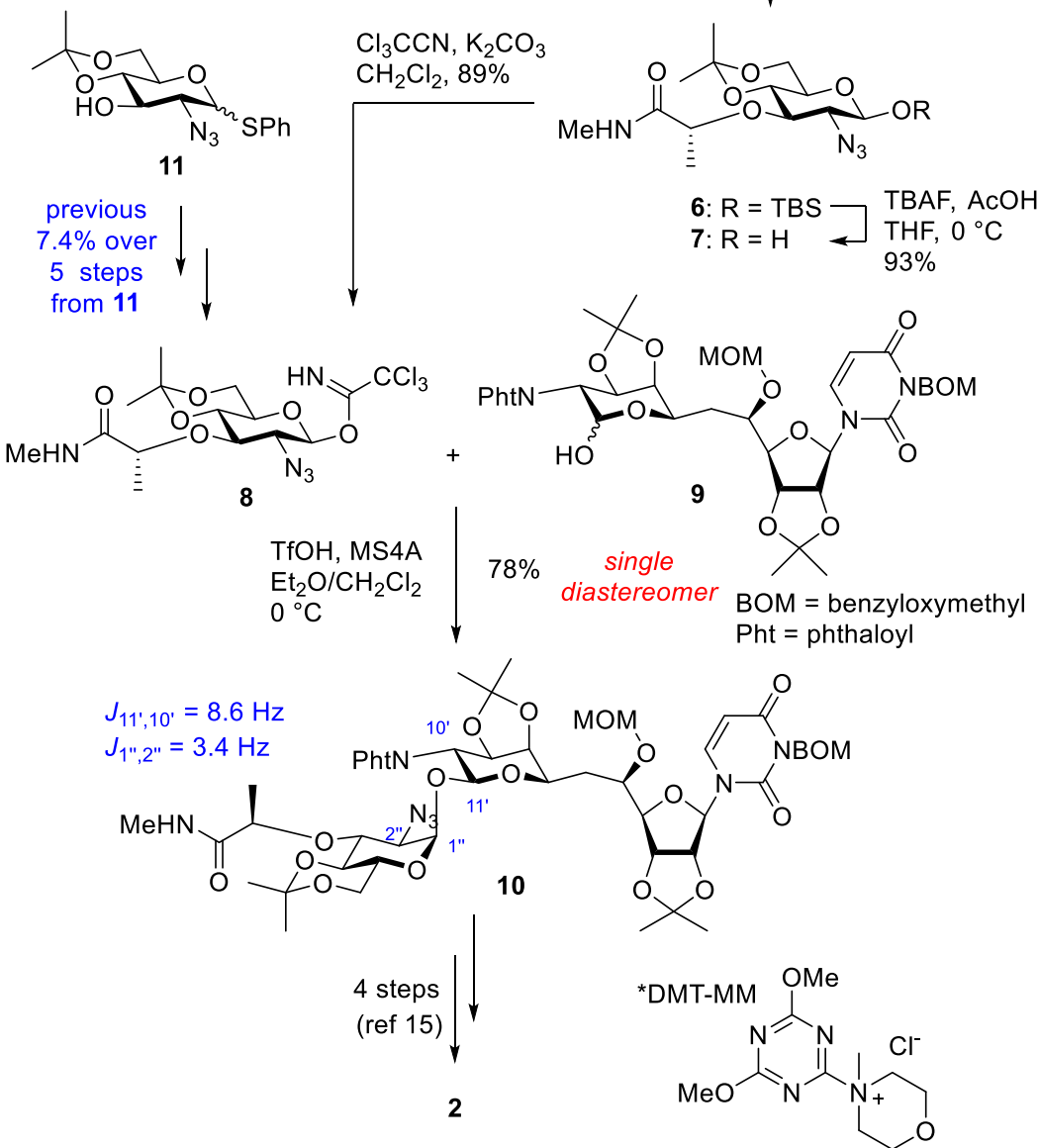


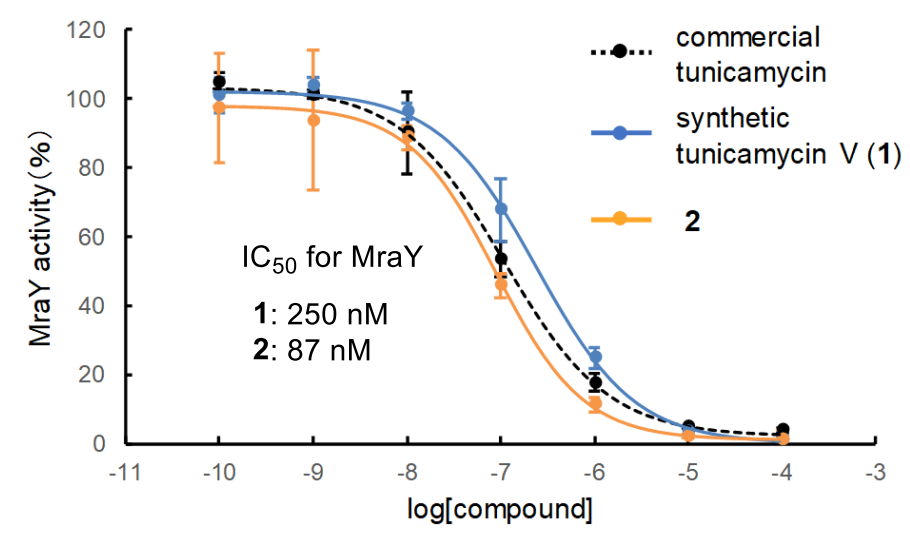

FIGURE 4. Flourescence-based MraY assay. ${ }^{a}$ The inhibitory activities of the compounds against purified MraY from S. aureus. Reaction was conducted with 50 $\mathrm{mM}$ Tris- $\mathrm{HCl}$ (pH 7.6), $50 \mathrm{mM} \mathrm{KCl}, 25 \mathrm{mM} \mathrm{MgCl}, 0.2 \%$ Triton X-100, 8\% glycerol, 100 mM C55-P, 100 mM UDPMurNAc-dansylpentapeptide, and MraY enzyme (11 ng/5 $\mathrm{mL} /$ well). After 3-4 $\mathrm{h}$ incubation at room temperature, the formation of dansylated lipid I was monitored by fluorescence en-hancement (excitation at $355 \mathrm{~nm}$, emission at $535 \mathrm{~nm}$ ). 


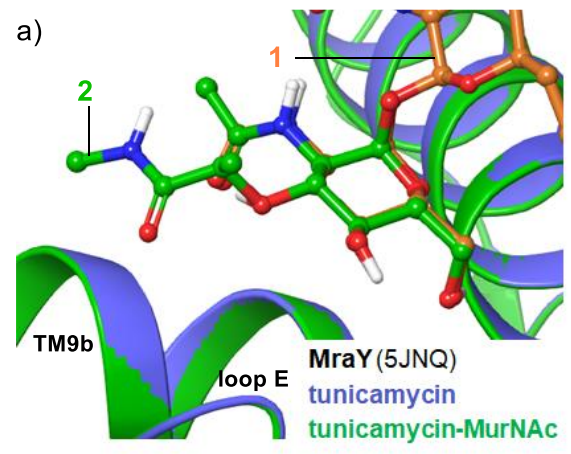

MBAE Del total energy $(\mathrm{kJ} / \mathrm{mol})$

1-MraY $_{\text {AA }} \quad-177.633$

2-MraY $_{\text {AA }} \quad-170.913$

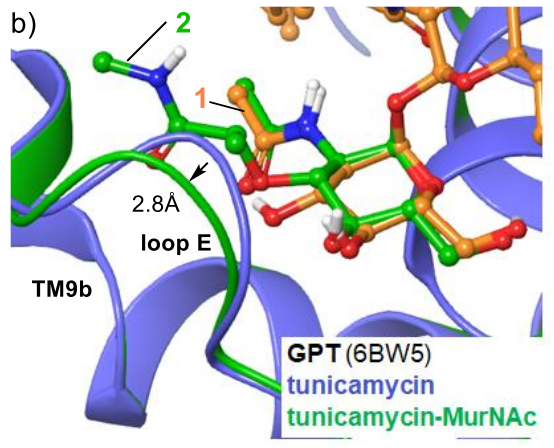

MBAE Del total energy $(\mathrm{kJ} / \mathrm{mol})$

1-GPT $\quad-187.791$

2-GPT $\quad-97.668$

FIGURE 5. Peoposed docking model of 2 bound to $\operatorname{MraY}_{\mathrm{AA}}$ (a) and GPT (b). Tunicamycin V (1, orage) and its analogue $\mathbf{2}$ (green) are represented by ball and stick model. MraY and GPT are repersented by cartoon models and those docked with 1 and $\mathbf{2}$ are colored by lavendar and green, respectively. Calculation was conducted by embrace minimization program; Force field OPLS-3, MacroModel ver. 11.5 


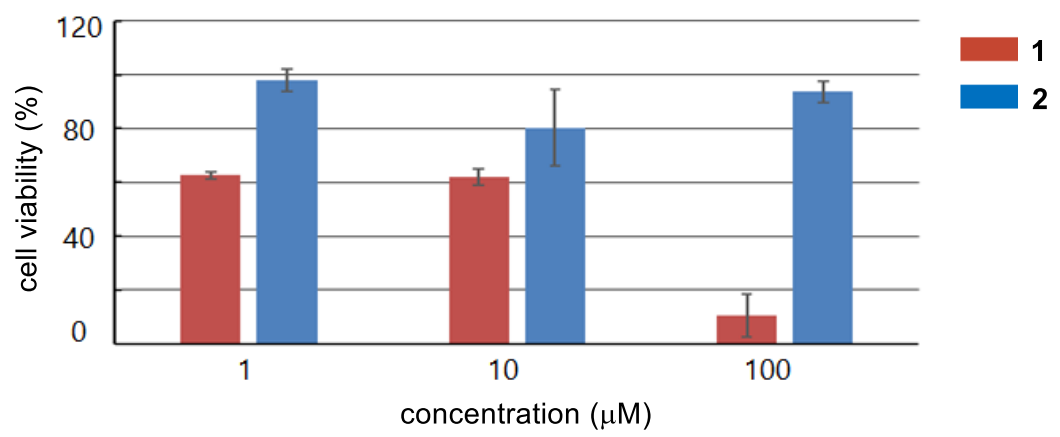

FIGURE 6. Cytotoxicity of 1 and $\mathbf{2}$ agains HepG2 cells. HepG2 cells $\left(1 \times 10^{4}\right.$ cells/well) in a 96-well plate were cultured in D-MEM (Low Glucose) containing $10 \%$ fetal bovine serum in the presence of test compounds at $37^{\circ} \mathrm{C}$ for $24 \mathrm{~h}$ under $5 \% \mathrm{CO}_{2}$ atmosphere. A solution of the Cell Counting Kit- 8 reagent was added. The plates were incubated at 37 ${ }^{\circ} \mathrm{C}$ for $24 \mathrm{~h}$ under $5 \% \mathrm{CO}_{2}$ atmosphere, and then absorbance was meacured at $450 \mathrm{~nm}$ 
TABLE 1. Antibacterial activity of $\mathbf{1}$ and $\mathbf{2}$

\begin{tabular}{lcc}
\hline & \multicolumn{2}{c}{ MIC $(\mu \mathrm{g} / \mathrm{mL})^{\mathrm{a}}$} \\
\cline { 2 - 3 } strains & $\mathbf{1}$ & $\mathbf{2}$ \\
\hline S. aureus ATCC25923 & 32 & 128 \\
K. pneumoniae ATCC13883 & $>128$ & $>128$ \\
A. baumannii ATCC19606 & $>128$ & $>128$ \\
E. cloacae ATCC13047 & $>128$ & $>128$ \\
$P$. aeruginosa ATCC27853 & $>128$ & $>128$ \\
E. faecium ATCC35667 & 128 & $>128$
\end{tabular}

${ }^{a}$ MICs were determined by a microdilution broth method as recommended by the CLSI with cationadjusted Mueller-Hinton broth (CA-MHB). Serial two-fold dilutions of each compound were made in appropriate broth, and the plates were inoculated with $5 \times 10^{4} \mathrm{CFU}$ of each strain in a volume of 0.1 $\mathrm{mL}$. Plates were incubated at $37^{\circ} \mathrm{C}$ for $18 \mathrm{~h}$ and then MICs were scored. 